\title{
VINASSE APPLICATION MANAGEMENT ON TWO SUGARCANE VARIETIES IN THE CERRADO GOIANO ${ }^{1}$
}

\author{
EDNA DAYANE DE BESSA ALMADA ${ }^{2 *}$, ANTÔNIO EVAMI CAVALCANTE SOUSA ${ }^{2}$, FREDERICO ANTÔNIO \\ LOUREIRO SOARES ${ }^{2}$
}

\begin{abstract}
Sugarcane is considered as one of the prominent agricultural crops in Brazil, with Goiás being the second largest national producer. During the processing of sugarcane, waste is generated, and one of these is vinasse. The objective of this study was to evaluate the biometric and technological performances of two varieties of sugarcane for different depths and vinasse parceling. Experiments were conducted at Fazenda Boa Sorte, located in the municipality of Carmo do Rio Verde-GO. A randomized block design was used with a subdivided plot containing two varieties of sugarcane (RB 86-7515 and SP 80-1816) and each subplot having three management types for the application of vinasse (M1 20-20 mm, M2 40-0 mm, and M3 30-30 mm) and four repetitions. The applications were performed in the months of May and June (dry period). The variables analyzed were the plant height, number of photosynthetically active green leaves, stem diameter, leaf area, stalk productivity, soluble solids content, broth pol, apparent sucrose content, fiber content, total reducing sugars, and reducing sugars. Analysis of variance was performed on the results obtained using the F test; subsequently, for the significant data, the test of means was performed. The SP 80-1816 variety showed superiority for both the biometric and technological variables. The ethanol yield and total recoverable sugar content were higher for the SP 80-1816 variety, with no difference between the vinasse application management. The vinasse application installment did not show viability.
\end{abstract}

Keywords: Saccharum officinarum. Fertigation. Yield. Nutrient recycling. Potassium fertilization.

\section{MANEJO DA APLICAÇÃO DA VINHAÇA EM DUAS VARIEDADES DE CANA-DE-AÇÚCAR NO CERRADO GOIANO}

RESUMO - A cana-de-açúcar é considerada uma das culturas agrícolas de maior destaque no Brasil, sendo o Goiás o segundo maior produtor nacional. Durante o processo de beneficiamento da cana-de-açúcar são gerados resíduos e um deles é a vinhaça. Objetivou-se avaliar o desempenho biométrico e tecnológico de duas variedades de cana-de-açúcar, sob aplicação de diferentes lâminas e parcelamento de vinhaça. O experimento foi conduzido na Fazenda Boa Sorte, localizada no município de Carmo do Rio Verde - GO. Foi utilizado o delineamento experimental de blocos casualizados, com parcela subdividida, sendo as parcelas duas variedades de cana-de-açúcar (RB 86-7515 e SP 80-1816) e as subparcelas três manejos da aplicação de vinhaça (M1 20 $20 \mathrm{~mm}, \mathrm{M} 2$ 40-0 mm e M3 30-30 mm), com quatro repetições. As aplicações ocorreram nos meses de maio e junho (período seco). As variáveis analisadas foram altura de planta, número de folhas verdes fotosinteticamente ativas, diâmetro do colmo, área foliar, produtividade de colmos, teor de sólidos solúveis, Pol do caldo, teor de sacarose aparente, teor de fibra, açúcares redutores totais, açúcares redutores. Para os resultados encontrados foi feita análise de variância pelo teste $\mathrm{F}$ e, posteriormente, para os dados significativos, foi feito o teste de média. A variedade SP80 - 1816 mostrou superioridade tanto para as variáveis biométricas, quanto para as variáveis tecnológicas. O rendimento de etanol e o teor de açúcares totais recuperáveis foram superiores para a variedade SP80 - 1816, não havendo diferença entre os manejos de aplicação de vinhaça. O parcelamento da aplicação de vinhaça não mostrou viabilidade.

Palavras-chave: Saccharum officinarum. Fertirrigação. Rendimento. Reciclagem de nutrientes. Adubação potássica.

\footnotetext{
${ }^{*}$ Corresponding author

${ }^{1}$ Received for publication in $09 / 24 / / 2019$; accepted in $10 / 26 / 2020$.

Paper extracted from the doctoral dissertation of the first author.

${ }^{2}$ Instituto Federal de Educação, Ciência e Tecnologia Goiano, Ceres, Goiás, GO, Brazil; ednna-almada@hotmail.com- ORCID: 0000-00030058-490X, antonio.sousa@ifgoiano.edu.br e ORCID: 0000-0002-0244-7143, frederico.soares@ifgoiano.edu.br e ORCID: 0000-00024152-5087.
} 


\section{INTRODUCTION}

Sugarcane is considered as a plant with great production potential for dry mass and energy supplementation and stands out among other crops for its easy adaptation to Brazilian climates; it has thus become one of the most cultivated crops in Brazil (OLIVEIRA; BRAGA; SANTOS, 2015).

In the current agricultural scenario, there is an expansion of the sugarcane cultivation areas in the national territory in Brazil, which shows the importance of this culture in the Brazilian economy. Brazil currently ranks as the world's second largest ethanol producer, next to the United States. According to the National Supply Company (CONAB), the production of sugarcane in the Midwest region in 2018 was 135 million tons. In Goiás, the sugarcane planted area was 909.8 thousand hectares, generating 69.1 million tons of harvested sugarcane, for a production of $1,749.7$ thousand tons of sugar and 5,059.5 million liters of ethanol (CONAB, 2018).

To maintain high productivity, factors such as the amount of water applied, irrigation management, soil type, climate, and variety must be taken into account (BAFFA; FREITAS; BRASIL, 2009). Therefore, among these characteristics, it is necessary to choose the variety that best adapts to the growing conditions; here, the RB 86-7515 and SP 80-1816 varieties are highlighted as the most cultivated in Brazil.

The RB 86-7515 has rapid development, mainly in the leaf area, which shows photosynthetic efficiency, has stalk and medium tillering for both plant and cane, and the plant itself is tall and erect. It is a drought-tolerant variety that tends to have high agricultural productivity when grown in ideal soils, along with high sucrose content, and good sprouting in cane plants and clogs (FAGUNDES; SILVA; BONFIM-SILVA, 2014; HOFFMANN et al., 2008; MARQUES; SILVA, 2008).

The SP 80-1816 variety is also widely cultivated for its high productivity and adaptation to Brazilian climates. Its production varies from medium to high, with excellent budding in ratoon, in addition to a high content of sucrose and fiber, which are currently the most essential target factors in the plants (LIMA, 2008).

However, to achieve all of this production potential, different irrigation models have been developed with the aim of benefiting from the cultivation of sugarcane, visualizing increase in productivity, and allowing greater efficiency in the use of fertilizers (BAFFA; FREITAS; BRASIL, 2009). In this sense, in addition to the various factors that influence the growth/development of the crop, for plants with increasing production tendencies, the choice of proper management is paramount. Vinasse has become a great target to achieve this goal, as the results obtained have been satisfactory considering that, according to Silva, Bono and Pereira (2014), vinasse when applied properly has the potential to increase crop productivity.

Thus, in addition to water irrigation techniques, vinasse management practices are also developed for the plants. The benefits of using vinasse are not only limited to meeting the water needs of sugarcane but also extended to the source of nutrients for the plant when applied properly, especially potassium. Considering this subject, the objective of this work was to evaluate the biometric and technological performances of two varieties of sugarcane in the plant cane cycle under application of different depths and vinasse parceling.

\section{MATERIALS AND METHODS}

Experiments were conducted in the municipality of Carmo de Rio Verde-GO, Brazil, at Boa Sorte Farm, located at the geographical coordinates $15^{\circ} 19^{\prime} 00$ "S latitude and $49^{\circ} 45^{\prime} 40^{\prime}$ O longitude at an altitude of $656 \mathrm{~m}$. The region's climate is classified as Aw, with dry and mild winters and hot and rainy summers, an average temperature of $24.6{ }^{\circ} \mathrm{C}$, with a minimum of $17.6^{\circ} \mathrm{C}$ in the months of May-June and maximum of $29.5^{\circ} \mathrm{C}$ between the months of January-February (CLIMATE-DATA.ORG, 2018).

The precipitation data shown in Figure 1 were collected using a rain gauge installed next to the experiment and was measured as a total of $1,063 \mathrm{~mm}$.

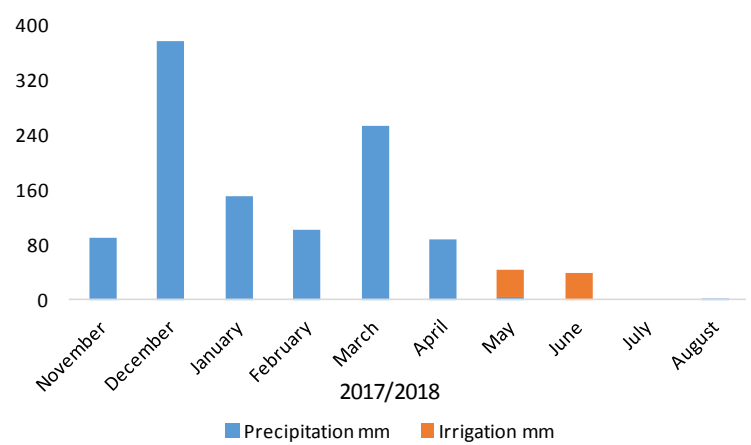

Figure 1. Precipitation recorded during the period in which the experiment was conducted, CRV, 2018. 
According to the Brazilian soil classification system, the soil in the experimental area is eutrophic Red Latosol (SANTOS et al., 2018), with a sandyclay-loam texture. The analysis of the soil sample from the experimental area, which was removed from a layer at a depth of 0 to $25 \mathrm{~cm}$ before planting, presented the following chemical characteristics: $\mathrm{pH}$ 5.00 in $\mathrm{CaCl}_{2} ; 104.70 \mathrm{mg} \mathrm{dm}{ }^{-3}$ of $\mathrm{P} ; 326.50 \mathrm{mg} \mathrm{dm}^{-3}$ of $\mathrm{K} ; 34.00 \mathrm{mg} \mathrm{dm}^{-3}$ of $\mathrm{S} ; 1.80 \mathrm{cmolc} \mathrm{dm}^{-3}$ of $\mathrm{Ca}$; 1.30 cmolc $\mathrm{dm}^{-3}$ of $\mathrm{Mg} ; 0.0$ cmolc $\mathrm{dm}^{-3}$ of $\mathrm{Al}$; $7.20 \mathrm{cmolc} \mathrm{dm}^{-3}$ of cation exchange capacity (CEC); base saturation equal to $54.00 \% ; 40.00 \mathrm{~g} \mathrm{dm}^{-3}$ of organic matter; $0.99 \mathrm{mg} \mathrm{dm}^{-3}$ of $\mathrm{Cu} ; 0.87 \mathrm{mg} \mathrm{dm}^{-3}$ of $\mathrm{Zn} ; 0.20 \mathrm{mg} \mathrm{dm}^{-3}$ of $\mathrm{B} ; 20.00 \mathrm{mg} \mathrm{dm}$ of $\mathrm{Fe}$; $6.51 \mathrm{mg} \mathrm{dm}^{-3}$ of $\mathrm{Mn}$. The analyses were performed according to the methodology proposed by Teixeira et al. (2017).

The soil preparation consisted of subsoiling at a depth of $40 \mathrm{~cm}$ for unpacking and a leveling grid was used immediately afterwards to break the clods. According to soil analysis, limestone was applied to achieve $70 \%$ base saturation, using $2.46 \mathrm{t} \mathrm{ha}^{-1}$ of limestone and $2.04 \mathrm{t} \mathrm{ha}^{-1}$ of plaster; further, $0.147 \mathrm{t} \mathrm{ha}^{-1}$ of urea were applied and the foundation was subsequently fertilized at the bottom of the furrow with the application of $0.524 \mathrm{t} \mathrm{ha}^{-1}$ of the formulation $05-25-25$, following the fertilization standards of the CRV plant.

The planting followed the patterns for CRV according to the conventional reduced type, semimechanized, with mechanized distribution, and the sugarcane sheets were then manually distributed before covering the furrows. The experimental design used was in randomized blocks (DBC), with a subdivided plot, considering two varieties in each plot and three vinasse application management types in each subplots: M1, two $20-20 \mathrm{~mm}$ split irrigation depths; M2, a 40-0 mm irrigation depth; and M3, two irrigation depths of $30-30 \mathrm{~mm}$, with four replications, totaling 24 experimental units.

The experimental plots had an average width of 320 meters, with six useful strips of 72 meters width or 48 lines of cane spaced 1.5 meters apart for the experiment; for data collection, the area of each plot was considered as 74 meters only. The experimental area was irrigated with vinasse, a residue obtained from the industrial CRV plant. According to the analysis, the vinasse applied in the first and second stages respectively had the following chemical characteristics: 0.28 and $0.46 \mathrm{~g} \mathrm{~L}^{-1}$ of $\mathrm{N} ; 0.11$ and 0.06 of $\mathrm{P} ; 1976.00$ and $1686 \mathrm{~kg} \mathrm{~m}^{-3}$ of $\mathrm{K}_{2} \mathrm{O} ; 1.98$ and $1.69 \mathrm{~kg} \mathrm{~m}^{-3}$ of $\mathrm{K}_{2} \mathrm{O}$; 0.53 and $0.49 \mathrm{~g} \mathrm{~L}^{-1}$ of $\mathrm{Ca} ; 0.29$ and $0.43 \mathrm{~g} \mathrm{~L}^{-1}$ of $\mathrm{Mg}$; 1.28 and $1.82 \mathrm{mg} \mathrm{L}^{-1}$ of $\mathrm{SO}_{4} ; 0.20$ and $0.31 \mathrm{mg} \mathrm{L}^{-1}$ of $\mathrm{Cu} ; 170$ and $83.00 \mathrm{mg} \mathrm{L}^{-1}$ of Fe; 3.4 and $2.80 \mathrm{mg} \mathrm{L}^{-1}$ of $\mathrm{Mn} ; 0.53$ and $1.00 \mathrm{mg} \mathrm{L}^{-1}$ of $\mathrm{Zn}$.

According to the results of the chemical analysis of vinasse, in the first and second stages, $734 \mathrm{~kg}$ of $\mathrm{K}_{2} \mathrm{O}$ were applied in the $\mathrm{M} 1$ treatment $(20-20 \mathrm{~mm}), 792 \mathrm{~kg}$ of $\mathrm{K}_{2} \mathrm{O}$ in the $\mathrm{M} 2$ treatment
(40 mm), and $1101 \mathrm{~kg}$ of $\mathrm{K}_{2} \mathrm{O}$ in the $\mathrm{M} 3$ treatment (30-30 $\mathrm{mm})$. The irrigation method used was selfpropelled mechanized sprinkling. The pump set used consisted of a TCA/series 10 engine of $1780 \mathrm{rpm}$, $140 \mathrm{HP}$, and connected to an IMBIL 100-500/2 pump with an average flow of $120 \mathrm{~m}^{3} \mathrm{~h}^{-1}$. The irrigation reel used was manufactured by the Irriga Brasil GSV/350 company, using a $140 \mathrm{~mm}$ hose of length 350 meters, with a Twin 202 Plus sprinkler gun for mounting the network and 6" Raesa high pressure tubing.

The applied management scheme was as follows: M1, an application of $40 \mathrm{~mm}$ of vinasse depth divided into two $20 \mathrm{~mm}$ steps; M2, $40 \mathrm{~mm}$ application in a single step; M3, $60 \mathrm{~mm}$ application of vinasse in two steps of $30 \mathrm{~mm}$ depth. The application interval for the slides was 34 days. Biometric analyses were performed during the crop development cycle using the verified plant height $(\mathrm{PH})$, number of leaves (NL), stem diameter (SD), leaf width (LW), leaf length (LL), and stalk productivity (PRO). For the biometric analysis, collections were made within the useful area of the plot, with the same plants being identified.

The plant height was determined by measuring the distance from the first node after cutting to the base of the leaf $(+1)$ of the plant. Following the methodology of Oliveira et al. (2010), the same scheme $(+1)$ was used to determine the length and width, with the aid of a tape measure. The stem diameter was measured between the first and second buds at the base with a digital caliper graduated in mm (DIGIMESS $\AA$ ). To calculate the leaf area, the following equation was used: Leaf length $(\mathrm{M}) \times$ Leaf width $(\mathrm{M}) \times 0.75 \times($ Number of leaves +2 ).

Five days before harvesting, samples of cane were collected to estimate the productivity of the stalks per hectare (PRO); this was performed for each of the 24 experimental plots. The methodology used included counting the number of plants within a two meter area using a tape measure, and cutting and weighing immediately afterwards using a portable digital scale with a hook. For technological analysis, ten bundles of plants were collected from each plot, totaling 240 plants. The material was duly identified and sent to the internal laboratory of the CRV industrial plant. The variables analyzed were soluble solids content (SSC), broth pol (BP), apparent sucrose content (POL), fiber content (fiber), total reducing sugars (TRS), reducing sugars (RS), total recoverable sugars (TSR), ethanol yield (EY), wet bagasse weight (WBW), and purity (PRT) according to the CONSECANA methodology (2006). Subsequently, the area was harvested. The data obtained were subject to analysis of variance by the $\mathrm{F}$ test, and the results showed a significant difference; hence, the Tukey test was performed at $5 \%$ probability, using the SISVAR statistical software. 
E. D. B. ALMADA et al.

\section{RESULTS AND DISCUSSION}

The average plant heights at 162 (PH1), 200 (PH2), 243 (PH3), and 277 (PH4) days after planting
(DAP) showed that there was a significant difference $(\mathrm{p}<0.01)$ (at 200 and 243 DAP) among the two varieties, with no significant effects on the management and interactive factors (Table 1).

Table 1. Summary of analysis of variance and comparison of the test of means for plant heights at 162 (PH1), 200 (PH2), 243 (PH3), and 277 (PH4) days after planting of the two varieties of sugarcane (RB 86-7515 and SP 80-1816) in the cane cycle with three vinasse application management types.

\begin{tabular}{|c|c|c|c|c|c|}
\hline \multirow{2}{*}{ Variation Source } & \multirow{2}{*}{ DF } & \multicolumn{4}{|c|}{ Medium Square } \\
\hline & & PH 1 & PH 2 & PH 3 & PH 4 \\
\hline Variety (V) & 1 & $0.47 \mathrm{~ns}$ & $1.53 * *$ & $2.21 * *$ & $0.82 \mathrm{~ns}$ \\
\hline BLOCK & 3 & $0.05 \mathrm{~ns}$ & $0.05 \mathrm{~ns}$ & $0.07 \mathrm{~ns}$ & $0.08 \mathrm{~ns}$ \\
\hline Residue a & 3 & 0.09 & 0.04 & 0.02 & 0.085 \\
\hline Management (M) & 2 & $0.02 \mathrm{~ns}$ & $0.00 \mathrm{~ns}$ & $0.02 \mathrm{~ns}$ & $0.04 \mathrm{~ns}$ \\
\hline Interaction $\mathrm{V} \times \mathrm{M}$ & 2 & $0.04 \mathrm{~ns}$ & $0.04 \mathrm{~ns}$ & $0.01 \mathrm{~ns}$ & $0.01 \mathrm{~ns}$ \\
\hline Residue b & 12 & 0.02 & 0.01 & 0.03 & 0.02 \\
\hline $\mathrm{CV}(\mathrm{a})$ & & 18.84 & 8.15 & 5.96 & 10.29 \\
\hline CV (b) & & 8.05 & 3.83 & 7.45 & 5.33 \\
\hline \multicolumn{2}{|l|}{ VARIETY } & \multicolumn{4}{|c|}{ AVERAGE } \\
\hline \multirow{2}{*}{\multicolumn{2}{|c|}{$\begin{array}{r}\text { RB 86-7515 } \\
\text { SP 80-1816 } \\
\end{array}$}} & $1.50 \mathrm{a}$ & $2.18 \mathrm{~b}$ & $2.08 \mathrm{~b}$ & $2.65 a$ \\
\hline & & $1.78 \mathrm{a}$ & $2.69 \mathrm{a}$ & $2.69^{a}$ & $3.02 \mathrm{a}$ \\
\hline \multicolumn{6}{|c|}{ APPLICATION MANAGEMENT } \\
\hline $20 \mathrm{~mm}-20 \mathrm{~mm}$ & & 1.66 & 2.43 & 2.33 & 2.75 \\
\hline $40 \mathrm{~mm}-0 \mathrm{~mm}$ & & 1.58 & 2.43 & 2.40 & 2.89 \\
\hline $30 \mathrm{~mm}-30 \mathrm{~mm}$ & & 1.67 & 2.44 & 2.43 & 2.87 \\
\hline
\end{tabular}

$* \mathrm{e}^{* *}$ significant at $5 \%$ and $1 \%$ probabilities by the $\mathrm{F}$ test, respectively; ns: not significant at $5 \%$ probability by the $\mathrm{F}$ test; DF: degree of freedom, CV: variation coefficient; letters next to the numbers indicate that there was a significant difference at the $5 \%$ probability level by the Tukey test.

At 200 DAP, plants of the SP 80-1816 variety presented heights that were $18.96 \%$ higher than those of the RB 86-7515 variety; at 200 DAP, this difference in plant height was $22.68 \%$. Rapid vegetative development and erect posture are characteristics of the SP 80-1816 variety (ZACURA FILHO; PICCIRILLI, 2012), which may have contributed to these results.

Macêdo et al. (2013) worked with the varieties RB 86-7515, RB 83-5486, SP 81-3250, SP 80-1816, RB 92-579, and RB 85-5536 in succession with different crops in a degraded pasture and found that at the age of 17 months, varieties RB 86-7515 and SP 80-1816 as well as varieties RB 92-579 and RB 85-5536, presented larger heights than the other varieties. This indicates that these varieties had greater heights even in degraded soils.

To compare the application of different doses of vinasse, Magalhães (2010) considered the varieties SP 80-1816 and RB 85-5453, compared vinasse doses of $0,120,240$, and $420 \mathrm{~m}^{3} \mathrm{ha}^{-1}$ and conventional potassium fertilization to observe that the plant heights subjected to doses of 240 and 420 $\mathrm{mm}$ did not differ from plants grown only with conventional fertilization, thus proving the nutritional potential of vinasse. This result can also be justified by the soil structure, where the Cerrado in Goiás presents soils with more clay textures and greater water retention capacities. For the stem diameter variable, there was a significant difference at $243 \mathrm{DBH}$ between the varieties and at $162 \mathrm{DBH}$ between the vinasse application management types. There were no significant difference between the interaction factors (Table 2).

At 243 DAP, it was observed that the stem diameter of the RB 86-7515 variety was $13.33 \%$ larger than that of the SP 80-1816 variety (Table 2). The RB 86-7515 has medium tillering, while the SP 80-1816 has high tillering. Based on the principle of the source/drain ratio, it is expected that materials with less tillering have larger stem diameters. As noted by Dillewijn (1952), the diameter varies according to the variety; however, the larger the diameter, the lower is the tillering of the clumps and lower is the productivity. 
E. D. B. ALMADA et al.

Table 2. Summary of analysis of variance for stem diameters at 162 (SD1), 200 (SD2), 243 (SD3), and 277 (SD4) DAP for two sugarcane varieties (RB 86-7515 and SP 80-1816) in the plant cane cycle subject to three vinasse application management types.

\begin{tabular}{|c|c|c|c|c|c|}
\hline \multirow{2}{*}{ Variation Source } & \multirow{2}{*}{ DF } & \multicolumn{4}{|c|}{ Medium Square } \\
\hline & & SD 1 & SD 2 & SD 3 & SD 4 \\
\hline Variety (V) & 1 & $31.64 \mathrm{~ns}$ & $27.24 \mathrm{~ns}$ & $115.50 *$ & $38.25 \mathrm{~ns}$ \\
\hline BLOCK & 3 & $15.62 \mathrm{~ns}$ & $4.53 \mathrm{~ns}$ & $0.70 \mathrm{~ns}$ & $3.68 \mathrm{~ns}$ \\
\hline Residue a & 3 & 24.36 & 3.94 & 4.86 & 4.67 \\
\hline Management (M) & 2 & $48.01^{*}$ & $0.98 \mathrm{~ns}$ & $5.39 \mathrm{~ns}$ & $5.32 \mathrm{~ns}$ \\
\hline Interaction $\mathrm{V} \times \mathrm{M}$ & 2 & $17.25 \mathrm{~ns}$ & $1.76 \mathrm{~ns}$ & $0.80 \mathrm{~ns}$ & $1.51 \mathrm{~ns}$ \\
\hline Residue b & 12 & 10.75 & 1.83 & 2.05 & 5.70 \\
\hline CV (a) & & 16.23 & 6.70 & 7.17 & 6.97 \\
\hline \multicolumn{2}{|l|}{$\mathrm{CV}(\mathrm{b})$} & 10.78 & 4.56 & 4.66 & 7.70 \\
\hline \multirow{2}{*}{\multicolumn{2}{|c|}{ VARIETY }} & \multicolumn{4}{|c|}{ AVERAGE } \\
\hline & & \multicolumn{4}{|c|}{$\mathrm{Mm}$} \\
\hline \multicolumn{2}{|l|}{ RB 86-7515 } & 31.57 & 30.69 & $32.93 \mathrm{a}$ & 32.28 \\
\hline \multicolumn{2}{|l|}{ SP 80-1816 } & 29.27 & 28.56 & $28.54 \mathrm{~b}$ & 29.75 \\
\hline \multicolumn{6}{|c|}{ APPLICATION MANAGEMENT } \\
\hline \multicolumn{2}{|c|}{$20 \mathrm{~mm}-20 \mathrm{~mm}$} & $27.62 b$ & 29.69 & 31.62 & 30.28 \\
\hline \multicolumn{2}{|l|}{$40 \mathrm{~mm}-0 \mathrm{~mm}$} & $31.47 \mathrm{ab}$ & 29.94 & 30.01 & 30.88 \\
\hline \multicolumn{2}{|l|}{$30 \mathrm{~mm}-30 \mathrm{~mm}$} & $32.17 \mathrm{a}$ & 29.25 & 30.57 & 31.89 \\
\hline
\end{tabular}

$* \mathrm{e} * *$ significant at $5 \%$ and $1 \%$ probabilities by the $\mathrm{F}$ test, respectively; ns: not significant at $5 \%$ probability by the $\mathrm{F}$ test; DF: degree of freedom, CV: variation coefficient; letters next to the numbers indicate that there was a significant difference at the $5 \%$ probability level by the Tukey test.

Campos et al. (2014), when evaluating 16 varieties of sugarcane subject to supplementary irrigation in the Cerrado of Goiás, found that the RB 86-7515 variety was among the ten varieties that obtained averages higher than 285 DAP, compared to other varieties, for the stalk diameter variable. Regarding the management of vinasse application, it was found that at $162 \mathrm{DAP}$, the stem diameter under 30-30 mm management was statistically greater than that at $20-20 \mathrm{~mm}$ and similar to the application of a single dose of $40 \mathrm{~mm}$ of stillage (Table 2). In the present study, the splitting of vinasse doses was not justified for this variable because the highest dose (30-30 mm) was statistically similar to a $40 \mathrm{~mm}$ dose applied once.

Magalhães (2010) found a linear increase in the diameter of the sugarcane stalk as a function of increase in vinasse dose applied, for the two varieties evaluated in the study, i.e., SP 80-1816 and RB 85-5453. There was a significant difference in the number of leaves at 200 and 243 DAP between these varieties, and a significant effect was also observed for interactions between the varieties and evaluated management types (Table 3 ).

When evaluating the effect of the vinasse application management factor on different varieties, it was found that, regarding the number of leaves, only variety SP80 -1816 showed significant effect. And when the varieties were compared for each management, only in the $20-20 \mathrm{~mm}$ and $40-0 \mathrm{~mm}$ managements there was a significant difference between the varieties (Table 4 ).

Table 4 shows that the SP 80-1816 variety under the $40 \mathrm{~mm}$ vinasse application management in a single step showed superior results for the number of leaves compared to the $30-30 \mathrm{~mm}$ application. The SP 80-1816 variety showed a greater number of leaves under the $20-20 \mathrm{~mm}$ and $40-0 \mathrm{~mm}$ managements for the RB 86-7515.

Maia Junior et al. (2018) evaluated six sugarcane cultivars, namely RB 72-910, RB 99-382, RB 72-454, RB 85-5536, RB 92-579, and RB 93-1011, and found significant differences in the number of leaves, with the RB 99-382 variety having the largest number of leaves at 240 DAP; further, the RB 85-5536 variety had fewer leaves over the same period Marques, Godinho and Almeida (2005) compared six varieties of sugarcane, namely RB 72-454, RB 85-5536, RB 86-7515, SP 81-3250, RB 84-5210, and SP 80-1816, in the edaphic conditions of Presidente Prudente-SP and did not find significant differences for the number of leaves. 
E. D. B. ALMADA et al.

Table 3. Summary of the analysis of variance for number of leaves at 162 (NL1), 200 (NL2), 243 (NL3), and 277 (NL4) DAP for two varieties of sugarcane subject to three application management types.

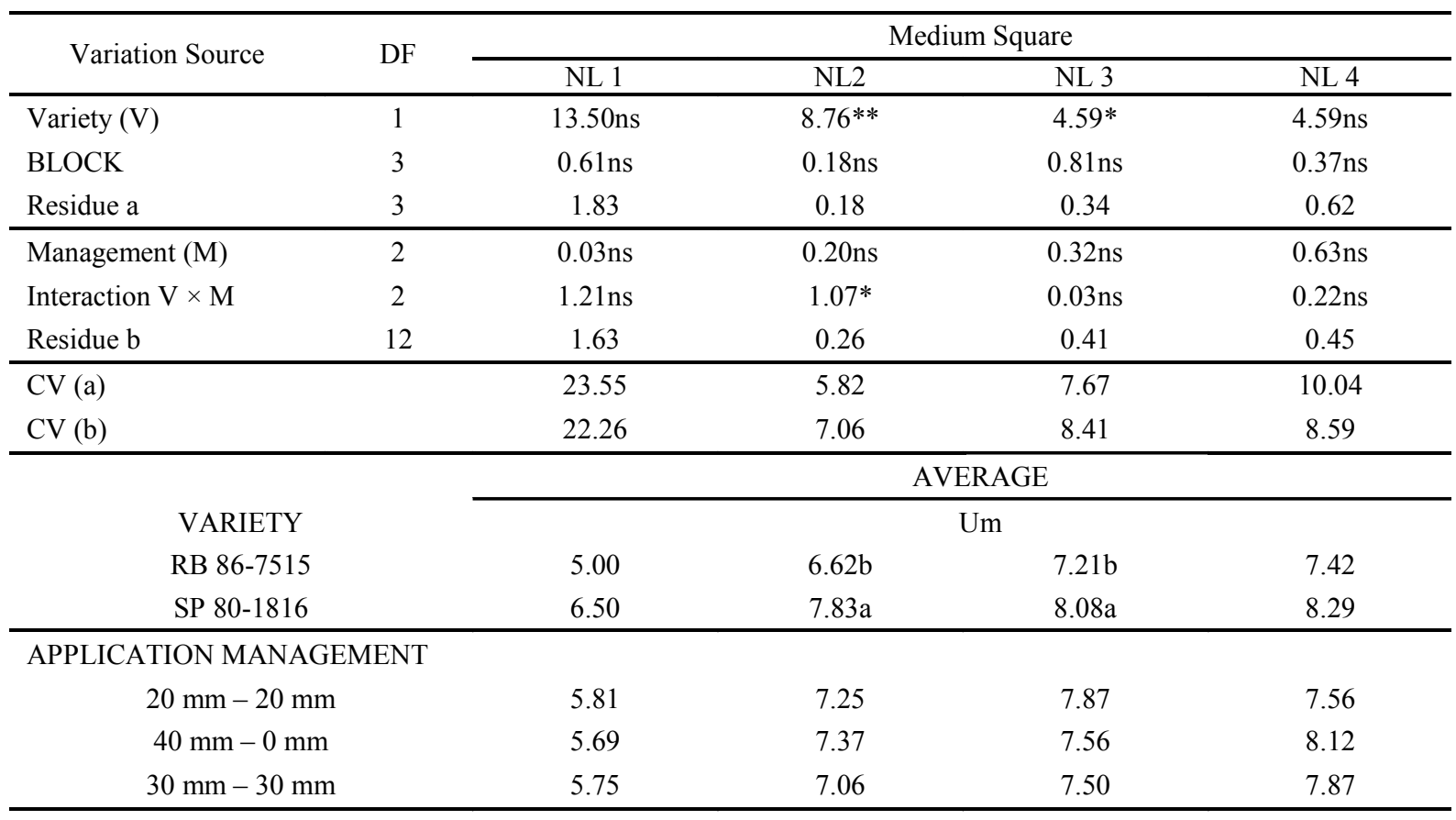

$* \mathrm{e}^{* *}$ significant at $5 \%$ and $1 \%$ probabilities by the $\mathrm{F}$ test, respectively; ns: not significant at $5 \%$ probability by the $\mathrm{F}$ test; DF: degree of freedom, CV: variation coefficient; letters next to the numbers indicate that there was a significant difference at the $5 \%$ probability level by the Tukey test.

Table 4. Breakdown of the interactions for the leaf number variable for two varieties of sugarcane in the plant cane cycle (RB 86-7515 and SP 80-1816) depending on levels and forms of vinasse application at 200 DAP.

\begin{tabular}{lccc}
\hline & \multicolumn{3}{c}{ NL aos 200 DAP (un) } \\
\hline \multirow{2}{*}{ Variety } & $20-20 \mathrm{~mm}$ & Management & $30-30 \mathrm{~mm}$ \\
\cline { 2 - 4 } & $6.50 \mathrm{bA}$ & $40-0 \mathrm{~mm}$ & $6.87 \mathrm{aA}$ \\
\hline RB 86-7515 & $8.00 \mathrm{aAB}$ & $6.50 \mathrm{Ba}$ & $7.25 \mathrm{aB}$ \\
\hline
\end{tabular}

Similar lowercase letters show that there were no significant differences between these varieties; Uppercase letters show that there were no significant differences between the management for the Tukey test at the 5\% probability level.

The leaf area variable showed no significant difference for the isolated and interactive factors at $162,200,243$, and 277 DAP. When only the variety factor was evaluated, it was found that the average values for RB 86-7515 and SP 80-1816 respectively varied from 0.56 to $0.59 \mathrm{~m}^{2}$ and from 0.46 to $0.68 \mathrm{~m}^{2}$. For the application management of 20-20 $\mathrm{mm}$, the average leaf area ranged from 0.39 to $0.65 \mathrm{~m}^{2}$, for $40-0 \mathrm{~mm}$, this ranged from 0.39 to $0.67 \mathrm{~m}^{2}$ and in the $30-30 \mathrm{~mm}$ case, it ranged from 0.61 to $0.73 \mathrm{~m}^{2}$.

According to Simões, Guimarães and Oliveira (2017), morphometric studies to determine the leaf area are useful for understanding the behaviors of plants in relation to nutritional, water, phytosanitary, and management factors, among others. Maia Júnior et al. (2018), when evaluating the six different sugarcane cultivars, noted that the leaf area together with the leaf width could be considered in the selection of cultivars for productive capacity, especially because they present good correlations between the weight and diameter of stalks. The varieties used showed significant effects for the total recoverable sugar, soluble solids content, broth pol, apparent sucrose content, and fiber content, and the SP 80-1816 variety showed superior results. There were no significant responses for the management and interactions between variety and management $(\mathrm{p}<0.05)$ (Table 5). 
E. D. B. ALMADA et al.

Table 5. Summary of analysis of variance of the two varieties (RB 86-7515 and SP 80-1816) for stem productivity (PRO), total recoverable sugar (TSR), soluble solids content (SSC), broth pol (BP), apparent sucrose content (POL), and fiber content (fiber) at 277 DAP for two varieties of sugarcane subject to three vinasse application management types.

\begin{tabular}{|c|c|c|c|c|c|c|c|}
\hline \multirow{2}{*}{ Variation Source } & \multirow{2}{*}{ DF } & & \multicolumn{5}{|c|}{ Medium Square } \\
\hline & & $\mathrm{PRO}^{1}$ & TSR & $\mathrm{SSC}$ & $\mathrm{BP}$ & POL & Fibra \\
\hline Variety $(\mathrm{V})$ & 1 & $8.0881 \mathrm{~ns}$ & $324.87 *$ & $20.72 *$ & $8.18^{*}$ & $13.39 * *$ & $3.62 *$ \\
\hline BLOCK & 3 & $1.0904 \mathrm{~ns}$ & $49.52 \mathrm{~ns}$ & $1.65 \mathrm{~ns}$ & $0.63 \mathrm{~ns}$ & $1.23 \mathrm{~ns}$ & $0.14 \mathrm{~ns}$ \\
\hline Residue a & 3 & 2.9726 & 24,04 & 0,99 & 0,24 & 0,36 & 0,32 \\
\hline Management (M) & 2 & $0.3384 \mathrm{~ns}$ & $139.75 \mathrm{~ns}$ & $1.24 \mathrm{~ns}$ & $1.18 \mathrm{~ns}$ & $1.91 \mathrm{~ns}$ & $0.08 \mathrm{~ns}$ \\
\hline Interaction $\mathrm{V} \times \mathrm{M}$ & 2 & $2.1656 \mathrm{~ns}$ & $107.79 \mathrm{~ns}$ & $0.59 \mathrm{~ns}$ & $0.30 \mathrm{~ns}$ & $0.29 \mathrm{~ns}$ & $0.05 \mathrm{~ns}$ \\
\hline Residue b & 12 & 3.3293 & 36.31 & 0.516 & 0.5 & 0.78 & 0.15 \\
\hline $\mathrm{CV}(\mathrm{a})$ & & 17.06 & 3.82 & 5.29 & 3.87 & 4.01 & 5.07 \\
\hline \multirow[t]{2}{*}{$\mathrm{CV}$ (b) } & & 18.06 & 4.69 & 3.82 & 5.82 & 5.92 & 3.43 \\
\hline & & & \multicolumn{5}{|c|}{ AVERAGE } \\
\hline \multicolumn{2}{|l|}{ VARIETY } & $\mathrm{tha}^{-1}$ & $\mathrm{~kg} \mathrm{t}^{-1}$ & ${ }^{\circ}$ Brix & $\%$ & $\%$ & $\%$ \\
\hline RB 86-7515 & & 118,59 & $124.35 b$ & $17.90 \mathrm{~b}$ & $12.19 b$ & $14.18 b$ & $10.81 \mathrm{~b}$ \\
\hline SP $80-1816$ & & 91,1 & $132.06 \mathrm{a}$ & $19.76 \mathrm{a}$ & $13.36 \mathrm{a}$ & $15.67^{\mathrm{a}}$ & $11.59^{\mathrm{a}}$ \\
\hline \multicolumn{8}{|c|}{ APPLICATION MANAGEMENT } \\
\hline $20 \mathrm{~mm}-20 \mathrm{~mm}$ & & 99,33 & 126.47 & 18.40 & 12.35 & 14.41 & 11.28 \\
\hline $40 \mathrm{~mm}-0 \mathrm{~mm}$ & & 102,94 & 133.33 & 19.17 & 13.10 & 15.39 & 11.25 \\
\hline $30 \mathrm{~mm}-30 \mathrm{~mm}$ & & 112,25 & 125.76 & 18.91 & 12.87 & 14.97 & 11.09 \\
\hline
\end{tabular}

$* \mathrm{e} * *$ significant at $5 \%$ and $1 \%$ probabilities by the $\mathrm{F}$ test, respectively; ns: not significant at $5 \%$ probability by the $\mathrm{F}$ test; DF: degree of freedom, CV: variation coefficient; letters next to the numbers indicate that there was a significant difference at the $5 \%$ probability level by the Tukey test.

${ }^{1}$ Data transformed into X-ray.

Tasso Júnior et al. (2007) observed in a study using vinasse in a dystrophic Red Latosol for the variety SP 81-3250 that in the cane plant, vinasse did not influence the productivity of stalks, while in cane soca (1st soca), there was a difference in the increment of culm production.

Silva et al. (2014) reported a study with five doses of vinasse $(0,100,200,400$, and $800 \mathrm{~m}^{3} \mathrm{ha}^{-1}$ year $^{-1}$ ) applied to RB-855536 and noted that the application of vinasse in the culture of sugarcane had the potential to increase stalk productivity by around $10.5 \mathrm{t} \mathrm{ha}^{-1}$ in sandy soils. These authors also found greater increases in stalk production with the application of vinasse in older cane fields and attributed this fact to the greater extraction of nutrients in the previous cuts, causing impoverishment of the soil over time.

The variety RB 86-7515 in the edaphoclimatic conditions of the region tends to have a later cycle and consequently may not have reached its peak of maturation during harvesting in August. The SP 80-1816 variety, on the other hand, presents harvest recommendations from the month of June, having been harvested in a period of complete maturation, thereby allowing complete expression of the total recoverable sugar (TRS). The total recoverable sugar was $5.93 \%$ higher in the SP 80 1816 variety compared to the RB $86-7515$ variety
(Table 5). Oliveira et al. (2012) found higher TRS values in their studies for the RB 85-5453 compared to the SP $80-1816$, with the possibility of reaching levels greater than $189.25 \mathrm{~kg}_{\text {of TRS t}}{ }^{-1}$.

Barbosa et al. (2013) did not verify the influence of fertigation as well with vinasse via subsurface drip irrigation on the values of total recoverable sugar during three cycles of cane growth. Prado et al. (2017), when evaluating the application of four doses of vinasse $(0,450,600$, and $750 \mathrm{~m}^{3} \mathrm{ha}^{-1}$ ) using the RB 85-5453 variety of sugarcane, found that an increase in vinasse dose caused an increase in the total reducing sugar, which is desirable for the sugar and alcohol industries. The TRS is important for both the industry and producers as it is the parameter for industrial unit used to determine the price paid to the producers (OLIVEIRA et al., 2012).

The content of soluble solids was $9.41 \%$ higher in the SP 80-1816 variety compared to the RB 86-7515 variety (Table 5) with complete maturation. Costa et al. (2011) evaluated four varieties of sugarcane, namely RB 92-579, SP 79-1011, RB 93-1530, and RB 93-509, in the fourth growing cycle, in the Tabuleiros Costeiros de Alagoas region and found a significant difference in the soluble solids content between the varieties. In their study, varieties RB 92-579 and RB 93-1530 had 
the highest values.

According to Pacheco (2012), the average values of the content of soluble solids in sugarcane for industrial purposes should be between 18 and $25{ }^{\circ}$ Brix. Thus, the RB $86-7515$ variety presented a value close to the ideal and the SP-1816 satisfactorily met the standard. Barbosa et al. (2013) found no significant difference in the content of soluble solids in sugarcane due to the use of vinasse. Table 5 also presents the results of Pol do broth, which was $8.75 \%$ higher in the SP $80-1816$ variety compared to the RB 86-7515 variety. Following the same trend, the SP 80-1816 variety showed an increase of $9.5 \%$ in apparent sucrose content compared to the RB 86-7515 variety. The more the content of sucrose, the more is the sugar content, which is nothing more than apparent sucrose and higher concentrated sugar.

Macêdo et al. (2013) also found a significant difference for these two variables when comparing six varieties of sugarcane (RB 86-7515, RB 83-5486, SP 81-3250, SP 80-1816, RB 92-579, and RB 85-5536), and for broth pol of RB 83-5486, which was superior to those of the others; for the content of apparent sucrose, the varieties RB 83-5486, SP 81-3250, and RB 85-5536 were superior than the others. The fiber content was $6.72 \%$ higher in the SP $80-1816$ variety compared to the RB 86-7515 variety (Table 5). Silva et al. (2014) studied the productive potential of sugarcane under drip irrigation for the IAC 91-1099, IACSP 96-3060, RB 85-5536, RB 86-7515, and SP 85-1115 varieties in two production cycles and found a significant difference in the content of fiber between the varieties only in the first production cycle. The average fiber contents observed by these authors were 13.6 and $12.8 \%$ in the first and second evaluation cycles, respectively, and the varieties that obtained the highest fiber values in the first cycle were IAC 91-1099, IACSP 96-3060, and SP 832847.

Costa et al. (2011) also observed a difference for this variable when evaluating four varieties of sugarcane in the fourth production cycle. These authors reported that the varieties SP 79-1011 and RB 93-509 showed superior results than the varieties RB 93-1530 and RB 92-579 and that the fiber values varied from 13.89 to $15.34 \%$. Some authors also note a direct relationship between the fiber content in sugarcane and application of vinasse, as in the example of Oliveira et al. (2009), who found that as the vinasse dose increased, the fiber content decreased linearly, indicating that for every $100 \mathrm{~m}^{3}$ of vinasse, an average retraction of $0.25 \%$ in the vinasse content could be expected.
According to Ripoli and Ripoli (2004), the percentage of fiber in the cane is directly reflected in the mill extraction efficiency, with this value being higher in materials with lower fiber content. However, the authors point out that varieties of sugarcane with low fiber content are more susceptible to mechanical damage caused by cutting and transport, which favors contamination and loss to the industry. When the cane is low in fiber, it may fall and be damaged by the wind, causing loss of sugar in the washing water. According to the authors, ideal fiber values are around 11 to $13 \%$. There was a significant difference in the total reducing sugars, yield of liters of alcohol and wet bagasse weight $(\mathrm{p}<0.01)$ between these varieties, with the SP 80-1816 being superior for the referred variables that showed significance. For reducing sugars and stem productivity, there were no significant differences between the isolated and interaction factors (Table 6).

The value of TRS sugars was $8.14 \%$ higher in the SP 80-1816 variety compared to the RB 86-7515 variety, which were respectively 14.78 and $13.76 \%$ (Table 6). Parazzi et al. (2018) evaluated five varieties of sugar cane (RB 97-5952, RB 96-6928, $\mathrm{RB}$ 85-5156, and RB 85-5453) and found that the varieties SP 81-3250 and RB 85-5156 were the only ones that differed from each other, since they had extreme values, that is, the highest and lowest values, respectively.

According to Pacheco (2012), ART determines the amount of TRS present in the sample, obtained by the total hydrolysis of sucrose. According to the author, based on the parameters of industrial interest, ART should be between 15 and 24\%. Ripoli and Ripoli (2004) also note that ART values must be greater than $15 \%$. In the present study, the values obtained did not reach the minimum values indicated by Pacheco (2012). The production of liters of alcohol per ton of processed cane was $8.40 \%$ higher in the SP $80-1816$ variety compared to the RB 86-7515 variety, whose average productions were 81.41 and $75.10 \mathrm{~L} \mathrm{ha}^{-1}$, respectively (Table 6). CONAB notes an average yield of hydrated ethyl alcohol of $83.3 \mathrm{~L}$ in the Center-South Region and $80 \mathrm{~L}$ in the NorthNortheast Region (CONAB, 2013). Therefore, the values observed in the present study show that the variety RB 86-7515 performed below the national average, whereas the variety SP 80-1816 showed performance within the average observed in the North-Northeast Region. The wet bagasse weight was $9.72 \%$ higher in the SP 80-1816 variety compared to the RB 86-7515 variety. 
E. D. B. ALMADA et al.

Table 6. Summary of analysis of variance for total reducing sugars (ART), reducing sugars (AR), ethanol yield (RE), wet bagasse weight (PBU), and purity (PRZ) at 277 DAP for two varieties of sugarcane (RB 86-7515 and SP 80-1816) in the plant cane cycle subject to three vinasse application management types.

\begin{tabular}{|c|c|c|c|c|c|c|}
\hline \multirow{2}{*}{ Variation Source } & \multicolumn{6}{|c|}{ Medium Square } \\
\hline & DF & TRS & $\mathrm{RS}$ & EY & WBW & PRT \\
\hline Variedade (V) & 1 & $8.83 *$ & $0.004 \mathrm{~ns}$ & $238.90^{*}$ & $566.77 *$ & $1.61 \mathrm{~ns}$ \\
\hline BLOCK & 3 & $0.67 \mathrm{~ns}$ & $0.004 \mathrm{~ns}$ & $26.87 \mathrm{~ns}$ & $22.35 \mathrm{~ns}$ & $4.38 \mathrm{~ns}$ \\
\hline Residue a & 3 & 0.29 & 0.0007 & 11.45 & 50.79 & 6.05 \\
\hline Manegement (M) & 2 & $1,17 \mathrm{~ns}$ & $0.003 \mathrm{~ns}$ & $34.40 \mathrm{~ns}$ & $13.17 \mathrm{~ns}$ & $0.78 \mathrm{~ns}$ \\
\hline Interaction $\mathrm{V} \times \mathrm{M}$ & 2 & $0.31 \mathrm{~ns}$ & $0.0005 \mathrm{~ns}$ & $10.07 \mathrm{~ns}$ & $7.63 \mathrm{~ns}$ & $3.38 \mathrm{~ns}$ \\
\hline Residue b & 12 & 0.5 & 0.007 & 17.50 & 23.19 & 5.12 \\
\hline CV (a) & & 3.73 & 3.32 & 4.32 & 5.52 & 3.11 \\
\hline \multirow[t]{2}{*}{$\mathrm{CV}(\mathrm{b})$} & & 4.93 & 10.33 & 5.35 & 3.73 & 2.86 \\
\hline & \multicolumn{6}{|c|}{ AVERAGE } \\
\hline \multicolumn{2}{|c|}{ VARIETY } & $\%$ & $\%$ & L.t $^{-1}$ & $\mathrm{Kg}$ & $\%$ \\
\hline \multicolumn{2}{|c|}{ RB $86-7515$} & $13.76 \mathrm{~b}$ & 0.81 & $75.10 \mathrm{~b}$ & $124.24 b$ & 78.79 \\
\hline \multicolumn{2}{|l|}{ SP $80-1816$} & $14.98 \mathrm{a}$ & 0.78 & $81.41 \mathrm{a}$ & $133.96 \mathrm{a}$ & 79.31 \\
\hline \multicolumn{7}{|c|}{ APPLICATION MANAGEMENT } \\
\hline \multicolumn{2}{|c|}{$20 \mathrm{~mm}-20 \mathrm{~mm}$} & 13.94 & 0.82 & 76.08 & 130.04 & 78.36 \\
\hline \multicolumn{2}{|c|}{$40 \mathrm{~mm}-0 \mathrm{~mm}$} & 14.69 & 0.78 & 80.21 & 129.63 & 79.65 \\
\hline \multicolumn{2}{|c|}{$30 \mathrm{~mm}-30 \mathrm{~mm}$} & 14.47 & 0.79 & 78.46 & 127.64 & 79.14 \\
\hline
\end{tabular}

$* \mathrm{e} * *$ significant at $5 \%$ and $1 \%$ probabilities by the $\mathrm{F}$ test, respectively; ns: not significant at $5 \%$ probability by the $\mathrm{F}$ test; DF: degree of freedom, CV: variation coefficient; letters next to the numbers indicate that there was a significant difference at the $5 \%$ probability level by the Tukey test.

Pacheco (2012) noted that the industry adopts values between 80 and $90 \%$ as ideal for the purity variable. However, we observe that in the present study, the values found were only close to the minimum value considered to be optimal. The fact that the treatments applied in installments of vinasse doses did not present a significant difference and can be related to the history of the experimental area, which was cultivated for sugarcane about ten years ago, with vinasse applied in this period. Consequently, the soil in the area has high levels of potassium and organic matter, which can mask/ mitigate the application management analysis of different doses of vinasse.

\section{CONCLUSION}

The management of fractionation of vinasse application independent of the blade influenced only the SD and NL of the sugarcane. The SP 80-1816 variety showed superiority both for the biometric variables $\mathrm{PH}, \mathrm{SD}$, and $\mathrm{NL}$, as well as for the technological TRS, SSC, BP, POL, FIBRA, TRS, WBW, and RY variables. The installment application of vinasse did not show viability, as it did not influence the productivity of sugar and ethanol. The increase in the depth dose of vinasse and its parceling did not increase the productivity of stalks and the ATR of sugarcane. However, the use of vinasse in fertigation is a viable alternative for correct destination utilization of this waste, in addition to providing the possibility of reducing the use of chemical fertilizers.

\section{ACKNOWLEDGMENT}

The authors would like to acknowledge the CRV Industrial Plant for the financing and support provided during all stages of conducting the experiments, to the Federal Goiano Institute Campus Ceres and all professors of the Postgraduate Program in Irrigation in the Cerrado, and to Capes, for the development of the Postgraduate Program in Irrigation in the Cerrado (PPGIC). 


\section{REFERENCES}

BARBOSA, E. A. A. et al. Cana-de-açúcar fertirrigada com vinhaça via irrigação por gotejamento subsuperficial em três ciclos de cana soca. Revista Brasileira de Engenharia Agrícola e Ambiental, Campina Grande, 17: 588-594, 2013.

BAFFA, D. C. F.; FREITAS, R. G. BRASIL, R.P.C. $O$ uso da vinhaça na cultura da cana-de-açúcar. Nucleus, Edição Especial: 31-45, 2009.

CAMPOS, P. F. et al. Variedades de cana-de-açúcar submetidas à irrigação suplementar no cerrado goiano. Engenharia Agrícola, 34: 1139-1149, 2014.

CLIMATE-DATA.ORG. Dados climáticos para cidades mundiais. Disponível em: <https:// pt.climate-data.org/>. Acesso em: 28 dez. 2018.

COMPANHIA

NACIONAL

DE ABASTECIMENTO - CONAB. Perfil do setor do açúcar e do álcool no Brasil. 1. ed. Brasília, DF: CONAB, 2013. 88 p.

COMPANHIA

NACIONAL

DE

ABASTECIMENTO - CONAB. Acompanhamento de safra de Cana-de-açúcar. 2018. Disponível em: $<$ https://www.conab.gov.br/info-agro/safras/cana $>$. Acesso em: 08 jan. 2019.

CONSELHO DOS PRODUTORES DE CANA-DEAÇÚCAR, AÇÚCAR E ALCOOL DO ESTADO DE SÃO PAULO - CONSECANA. Manual de instruções. 5th ed. Piracicaba, 2006. 200 p.

COSTA, C. T. S. et al. Crescimento e produtividade de quatro variedades de cana-de-açúcar no quarto ciclo de cultivo. Revista Caatinga, 24: 56-63, 2011.

DILLEWIJN, V. C. Botany of sugarcane. Waltham: the chronica Botânica, 1952. 371 p.

FAGUNDES, E. A. A.; SILVA, T. J. AD; BONFIMSILVA, E. M. B. Desenvolvimento inicial de variedades de cana-de-açúcar em latossolo submetidas a níveis de compactação do solo. Revista Brasileira de Engenharia Agrícola e Ambiental, 18: 188-193, 2014.

HOFFMANN, H. P. et al. Variedades rb de canade-açúcar. 1. ed. Araras, SP: CCA/UFSCar, 2008. $30 \mathrm{p}$.

LIMA, R. M. P. Caracterização de variedades de cana-de-açúcar quanto à resistência e tolerância ao raquitismo da soqueira, 2008. 56 f. Dissertação (Mestrado em Genética Vegetal: Área de Concentração em Genética e Melhoramento de Plantas). Universidade Estadual do Norte
Fluminense Darcy Ribeiro - UENF. Rio de Janeiro.

MACÊDO, G. A. R. et al. Características produtivas e tecnológicas de variedades de cana-de-açúcar em sucessão a diferentes cultivos em pastagem degradada. Revista Brasileira de Ciências Agrárias, 8: 223-228, 2013.

MAGALHÃES，V. R. Influência de doses de vinhaça nas características agronômicas de variedades de cana-de-açúcar, cana planta e atributos químicos do solo. 2010. 89 f. Dissertação (Mestrado em Produção Vegetal no Semiárido: Área de concentração em Produção Vegetal). Universidade Estadual de Montes Claros Unimontes, Janaúba. 2010.

MAIA JÚNIOR, S. D. O. et al. Caracterização morfológica e produtiva e suas correlações em cultivares de cana-de-açúcar. Revista Ciência Agrícola, 16: 31-42, 2018.

MARQUES, T. A.; SILVA, W. H. Crescimento vegetativo e maturação em três cultivares de cana-de -açúcar. Revistã de Biologia e Ciências da Terra, 8: 54-60, p. 2008.

MARQUES, T. A.; GODINHO, A. M. M.; ALMEIDA, R. A. M. Atributos morfológicos de seis cultivares de cana-de-açúcar no pleno desenvolvimento vegetativo. Colloquium Agrariae, 1: 16-21, 2005

OLIVEIRA, E. L. et al. Uso de vinhaça de alambique e nitrogênio em cana-de-açúcar irrigada e não irrigada. Pesquisa Agropecuária Brasileira, 44: 1398-1403, 2009.

OLIVEIRA, E. C. A. et al. Crescimento e acúmulo de matéria seca em variedades de cana-de-açúcar cultivadas sob irrigação plena. Revista Brasileira de Engenharia Agrícola e Ambiental, 14: 951-960, 2010 .

OLIVEIRA, F. M. D. et al. Avaliação tecnológica de variedades de cana-de-açúcar influenciadas por diferentes adubações e supressões de irrigação. Revista Ceres, 59: 832-840, 2012.

OLIVEIRA, A. R. D; BRAGA, M. B.; SANTOS, B. L. S. Produção de biomassa de cana-de-açúcar no vale do São Francisco. Revista Energia na agricultura, 29: 27, 2015.

PACHECO, T. F. Tecnologia industrial. In: MAY, A. et al. (Eds.). Sistema Embrapa de produção agroindustrial de sorgo sacarino para bioetanol: Sistema BRS1G - Tecnologia Qualidade Embrapa. Sete Lagoas, MG: Embrapa Milho e Sorgo, 2012. v. 1, cap. 11, p. 85-91. 
PARAZZI, C. et al. Estudo da qualidade físicoquímica, tecnológica e sensorial de caldos de cana-de -açúcar para consumo. Revista Cincia, Tecnologia \& Ambiente, 8: 3-10, 2018.

PRADO, E. A. F. D. et al. Características tecnológicas da cana-de-açúcar sob aplicação de doses de vinhaça em Latossolo Vermelho distroférrico. Revista de ciências agroveterinárias, 16: 386-395, 2017.

RIPOLI, T. C. C.; RIPOLI, M. L. C. Biomassa de cana-de-açúcar: colheita, energia e ambiente. 1. ed. Piracicaba, SP: Barros \& Marques Editoração Eletrônica, 2004. 302 p.

SANTOS, H. G. et al. Sistema brasileiro de classificação de solos. 5. ed. Brasília, DF: Embrapa, 2018. $356 \mathrm{p}$.

SILVA, A. P. M. D; BONO, J. A. M.; PEREIRA, F. D. A. R. Aplicação de vinhaça na cultura da cana-deaçúcar: efeito no solo e na produtividade de colmos. Revista Brasileira de Engenharia Agrícola e Ambiental, 18: 38-43, 2014.

SILVA, M. D. A. et al. Potencial produtivo da canade-açúcar sob irrigação por gotejamento em função de variedades e ciclos. Revista Brasileira de Engenharia Agrícola e Ambiental, 18: 241-249, 2014.

SIMÕES, W. L.; GUIMARÃES, M. J M.; OLIVEIRA, A. R. Estimativa da área foliar de variedades de cana-de-açúcar no Submédio do Vale do São Francisco. Petrolina, PE: Embrapa Semiárido, 2017. 18 p.

TASSO JÚNIOR, L. C. et al. Produtividade e Qualidade de Cana-de-açúcar cultivada em solo tratado com lodo de esgoto, vinhaça e adubos minerais. Engenharia Agrícola, 27: 276-283, 2007.

TEIXEIRA, P. C. et al. Manual de métodos de análise de solo. Brasília, DF: Embrapa. 3. ed, 2017, $574 \mathrm{p}$.

ZACURA FILHO, G.; PICCIRILLI, J. P. O processo de fabricação do açúcar e do álcool desde a lavoura da cana até o produto acabado. 1 ed. São Paulo, SP: Editora Viena, 2012. 272 p. 